\title{
Biology and Management of Economically Important Lepidopteran Cereal Stem BORERS IN Africa
}

\author{
Rami Kfir, ${ }^{1}$ W. A. Overholt, ${ }^{2}$ Z. R. Khan, ${ }^{2}$ and A. Polaszek ${ }^{3}$ \\ ${ }^{1}$ ARC-Plant Protection Research Institute, Private Bag X134, Pretoria 0001, \\ South Africa; e-mail: rietrk@plant2.agric.za \\ ${ }^{2}$ International Centre of Insect Physiology and Ecology, P.O. Box 30772, \\ Nairobi, Kenya; e-mail: woverholt@icipe.org; zkhan@icipe.org \\ ${ }^{3}$ CABI Bioscience UK Centre, Entomology Department, Imperial College at \\ Silwood Park, Ascot, Berkshire SL5 7PY United Kingdom; e-mail: a.polaszek@ic.ac.uk
}

Key Words maize, diapause, competition, pheromones, cultural control, biological control, IPM

- Abstract Cereals (maize, sorghum, millet, rice) are extremely important crops grown in Africa for human consumption. Of the various insect pests attacking cereal crops in Africa, lepidopteran stem borers are by far the most injurious. All 21 economically important stem borers of cultivated grasses in Africa are indigenous except Chilo partellus, which invaded the continent from India, and C. sacchariphagus, which has recently been found in sugarcane in Mozambique. C. partellus is competitively displacing indigenous stem borers in East and southern Africa. A parasitoid, Cotesia flavipes, was introduced from Pakistan for biological control of $C$. partellus and caused a $32-55 \%$ decrease in stem borer densities. This article is an attempt to summarize the status of knowledge about economically important cereal stem borers in Africa with emphasis on their distribution, pest status and yield losses, diapause, natural enemies, cultural control, host plant resistance, and biological control. Special attention is given to Busseola fusca and C. partellus, the most important pests of maize and grain sorghum.

\section{CONTENTS}

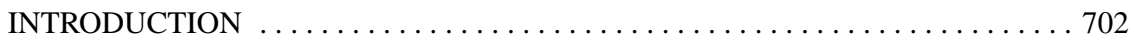

STEM BORERS AND THEIR DISTRIBUTION $\ldots \ldots \ldots \ldots \ldots \ldots \ldots \ldots \ldots \ldots . \ldots \ldots 7$

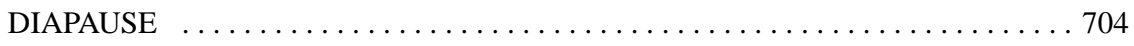

DISPLACEMENT OF NATIVE STEM

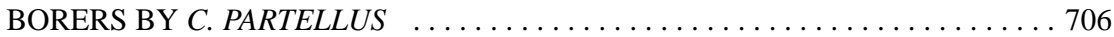

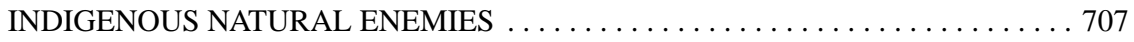

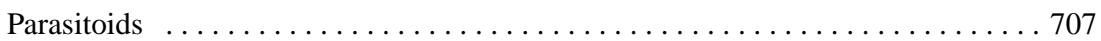

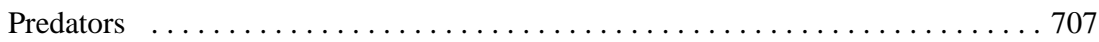

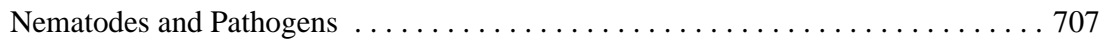




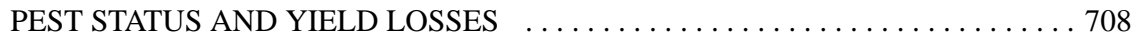

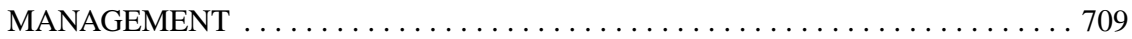

Utilization of Synthetic Sex Pheromones … . . . . . . . . . . . . . . 709

Cultural Control . . . . . . . . . . . . . . . . . . . . . . . . . . . . 710

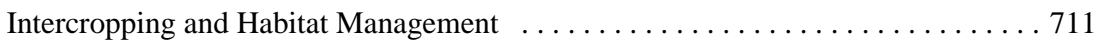

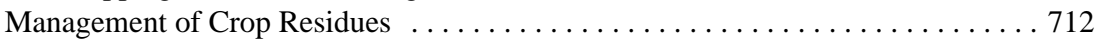

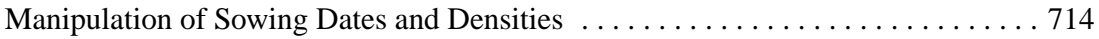

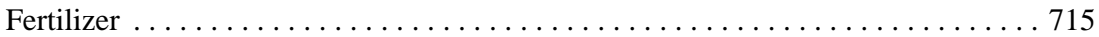

Host Plant Resistance $\quad \ldots . \ldots \ldots \ldots \ldots \ldots \ldots \ldots$. . . . . . . . . . . . . . . . 715

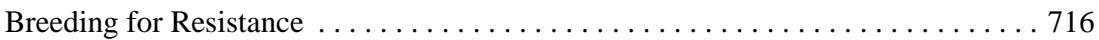

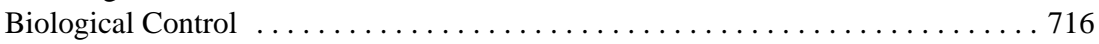

\section{INTRODUCTION}

Cereals, especially maize and sorghum, are the most important field crops grown in Africa by commercial and resource-poor small-scale farmers $(94,167)$. Sugarcane is also an important cash crop grown in some areas. The crops are grown primarily for human consumption, but surpluses are used for feeding livestock (176). Among the insect pests attacking these crops in Africa, the lepidopteran stem borers are by far the most injurious (224). Because of their economic importance, stem borers have been the subjects of many studies, which resulted in an enormous amount of literature. This review summarizes the status of knowledge about cereal stem borers in Africa.

\section{STEM BORERS AND THEIR DISTRIBUTION}

Maes (105) listed 21 economically important lepidopteran stem borers of cultivated grasses in Africa, including 7 noctuids, 2 pyralids, and 12 crambids. Of these 21 species, 7 are primarily pests of rice, and one mainly attacks pearl millet in the Sahelian region. Among the noctuids, Busseola fusca and six Sesamia spp. are considered economically important. Two pyralids are serious pests: the rice borer, Maliarpha separatella, and Eldana saccharina, a pest of sugarcane and maize. The largest group (12 species) of injurious stem borers are crambids, with the majority ( 7 species) belonging to the genus Chilo Zincken. Within specific crops and geographic regions, fewer species are considered to be important pests (Table 1).

In South Africa, B. fusca and Chilo partellus are the only important stem borers of maize and sorghum (94), while in sugarcane in the same region, only E. saccharina is considered to be a serious pest (47). In East Africa, C. partellus, Chilo orichalcociliellus, E. saccharina, B. fusca, and Sesamia calamistis are mentioned as important and widely distributed stem borers of maize and sorghum (168). Major stem borers of maize and sorghum in West Africa include B. fusca, S. calamistis, and E. saccharina (34). In the Sahelian zone, where pearl millet is the most important cereal crop, Coniesta ignefusalis is the dominant stem borer (73). 
TABLE 1 Important stemborer species in Africa and the Indian Ocean Islands, their distributions, and major cultivated host plants

\begin{tabular}{|c|c|c|c|c|}
\hline Family & Species & Distribution & Host plants & Reference \\
\hline \multirow[t]{9}{*}{ Crambidae } & Chilo partellus & eastern and southern & maize, sorghum & (71) \\
\hline & Chilo orichalcociliellus & $\begin{array}{l}\text { coastal eastern, Malawi, } \\
\text { Madagascar; South } \\
\text { Africa, Zimbabwe }\end{array}$ & maize, sorghum & (29) \\
\hline & Chilo aleniellus & West and Central & rice, maize & $(120)$ \\
\hline & Chilo sacchariphagus & Indian Ocean Islands; & sugarcane & $(222)$ \\
\hline & & Mozambique & sugarcane & (209) \\
\hline & Chilo zacconius & West & rice & (105) \\
\hline & Chilo diffusilineus & tropical Africa & rice & (105) \\
\hline & Coniesta ignefusalis & Sahelian Africa & millet & (73) \\
\hline & Scirpophaga spp. & West & rice & (40) \\
\hline \multirow[t]{2}{*}{ Pyralidae } & Eldana saccharina & sub-Saharan & $\begin{array}{l}\text { sugarcane, } \\
\text { maize, rice }\end{array}$ & (23) \\
\hline & Maliarpha separatella & $\begin{array}{l}\text { sub-Saharan, Indian } \\
\text { Ocean Islands }\end{array}$ & rice & (48) \\
\hline \multirow[t]{4}{*}{ Noctuidae } & Busseola fusca & sub-Saharan & maize, sorghum & (72) \\
\hline & Sesamia calamistis & sub-Saharan & maize, sorghum, rice & (187) \\
\hline & $\begin{array}{l}\text { Sesamia nonagrioides } \\
\text { botanephaga }\end{array}$ & West, Sudan & $\begin{array}{l}\text { maize, rice, } \\
\text { sorghum, sugarcane }\end{array}$ & (187) \\
\hline & Sesamia cretica & Northeast & sorghum, maize & $(187)$ \\
\hline
\end{tabular}

Information on rice stem borers is primarily from West Africa and the Indian Ocean Islands, as these are areas where rice is an important food crop. Chilo zacconius, $M$. separatella, and $S$. calamistis are considered the most economically important stem borers of rice in West Africa $(13,37)$. M. separatella is the only rice borer that has a widespread distribution in sub-Saharan Africa, and it also occurs in the Comoro Islands and Madagascar (37). Other rice stem borers of secondary importance in West Africa include Scirpophaga spp., Chilo diffusilineus, and Sesamia nonagriodes botanephaga $(37,38)$. Additionally, Chilo aleniellus is reported to be a rice stem borer in Ivory Coast $(189,190)$.

Two of the economically important cereal stem borers in Africa are introduced species: C. partellus and C. sacchariphagus. C. partellus is an Asian species (29) that invaded Africa sometime before 1930 when it was first recorded in Malawi (186), but it was not reported again until some 20 years later in Tanzania (53). The distribution of C. partellus now includes Ethiopia, Sudan, Somalia, Kenya, Tanzania, Uganda, Mozambique, South Africa, Swaziland, Lesotho, Zimbabwe, Zambia, Malawi, and Botswana $(41,71,79,127)$. Using GIS tools, Overholt et al. (145) predicted the eventual distribution of $C$. partellus in Africa based on the climate at locations where it was known to occur and then extrapolating to other locations with similar climates. The prediction included several countries in southwestern and West Africa where $C$. partellus is not yet known to occur. 
The other invasive species, $C$. sacchariphagus, is a serious pest of sugarcane in the Indian Ocean Islands. $C$. sacchariphagus may have been accidentally introduced into the islands either from Sri Lanka or Java with the introduction of sugarcane around 1850 (222). There are recent confirmed reports of C. sacchariphagus attacking sugarcane in Mozambique (209).

Some of the more important native species have restricted distributions, whereas others are found throughout sub-Saharan Africa. C. orichalcociliellus, a pest of maize and sorghum, occurs in coastal East Africa, Malawi, and Madagascar at altitudes below $600 \mathrm{~m}(51,108,127)$. C. aleniellus has been reported as a pest of rice in West and Central Africa and more recently as an important pest of maize in Ivory Coast (120). C. ignefusalis is the dominant stem borer of millet in the Sahelian zone of West Africa (69).

E. saccharina is widely distributed in Africa and has been reported from several grasses and sedges $(23,45,61,78)$. In southern Africa, E. saccharina is a major pest of sugarcane but rarely causes damage in maize (177). In contrast, E. saccharina is considered to be a pest of maize, sugarcane, and rice in West Africa $(32,64,159,174)$.

B. fusca and Sesamia spp. occur throughout subsaharan Africa (79). Of the Sesamia spp., S. calamistis is the most widely distributed and economically important species, but several others, including $S$. cretica, which occurs in Somalia, Sudan, and Ethiopia, and S. nonagrioides botanephaga, which is found in both East and West Africa, are also important. As with E. saccharina, the pest status of $B$. fusca varies by region. In East and southern Africa it is a pest at higher altitudes $(>600 \mathrm{~m})(127,178)$, but in West Africa, B. fusca occurs from sea level to $>2000 \mathrm{~m}$ (187) but is primarily a pest in the dry savanna zone (68).

\section{DIAPAUSE}

Many cereal stem borers have a resting period toward the end of the cropping season, which they spend as fully grown larvae in dry crop residues in the fields. In Kenya, C. partellus, S. calamistis, and C. orichalcociliellus enter diapause for several months in the dry season $(130,161,163)$. However, $S$. calamistis was reported not to enter diapause in Uganda (78) or in Nigeria (68). In West Africa, B. fusca enters diapause during the dry season, and it takes up to six months to complete development. With the initiation of the rains, the larvae pupate within the stems, and 10-12 days later adult moths emerge (68). Similar observations were made on $C$. ignefusalis, which has a facultative diapause in dry millet stems (226).

In southern Africa, B. fusca and C. partellus pass winter in diapause, which is the cold dry season (April-September), in the lower parts of the dry stalks, where they are well protected from natural enemies and adverse climatic conditions (83-85). B. fusca diapauses throughout its distribution in Africa, whereas $C$. partellus does not diapause in the warm low-lying regions of the South African Provinces of Kwazulu-Natal (203) and Mpumalanga (R. Kfir, unpublished data), Swaziland 
(218), and southern Mozambique (27). In regions where there is an abundance of host plants and the climate is warm, C. partellus normally develops continuously all-year round. In other regions with long dry periods in winter or in summer, the borer enters into a resting period. C. partellus was reported to diapause in the dry season in India (187) and on several islands off the coast of Africa $(39,51)$. However, populations without a resting period were reported from the Coast Province of Kenya (108) and Uganda (78). This explains the mixed populations of $C$. partellus found in the dry season on the Kenya Coast and at lower elevations in South Africa. In the coastal area of Kenya, in periods between cropping seasons, some stem borers diapause in maize stubble, whereas others remain actively feeding in wild grasses, such as Napier grass, in the proximity of cultivated areas (124).

An increase in carbohydrates and decrease in protein and water of the food plant are the main factors inducing diapause in B. fusca (193). Dry condition of the host plant (127) and the general deterioration of the nutritive environment $(51,160)$ induced diapause in larvae of $C$. partellus even when climatic conditions were favorable for development (161). Diapause could be artificially induced in nondiapause larvae introduced into aged maize stems.

During diapause, larvae of $B$. fusca and $C$. partellus progressively decreased in weight and had up to seven additional stationary molts. The longer time the larvae remained in diapause, the lighter in weight the emerging adults were, with fewer eggs and oocytes in their ovaries. After eight months in diapause, emerging adults weighed about half as much and had about half as many eggs and oocytes as adults that emerged from nondiapausing larvae (86).

Diapausing larvae of field-collected B. fusca in South Africa collected in winter emerged as adults in mid-October regardless of the date of collection and the length of time they were kept in the laboratory at $21^{\circ} \mathrm{C}$ and $60 \%$ relative humidity. Larvae of $C$. partellus collected in April-June emerged in November, whereas those collected in July emerged in October and those collected in August emerged in September. Regardless of the collection date, $C$. partellus started to emerge from diapause earlier, and the emergence period lasted up to twice as long as in B. fusca. Kfir (85) concluded that B. fusca had an obligatory diapause and C. partellus a facultative diapause. In the field, $C$. partellus starts to emerge from diapause in the second part of August, and it continues until the first week of November, a period of 12 weeks. In contrast, $B$. fusca pupates only during October-November $(83,85,95)$. This difference in the pattern of emergence from diapause by the two borer species explains the distinct generations of $B$. fusca $(54,95,106)$ and the overlapping generations of $C$. partellus $(85,205)$ occurring every year in South Africa.

Conditions of continuous moisture during the long rainy season in Kenya play a significant role in the termination of diapause by B. fusca $(135,137)$. Rainfall alone did not appear to be the main factor (192). Contact with water was a more significant factor in diapause termination than water uptake (136). Application of water or rainfall played an important role in promoting pupation during postdiapause dormancy of $B$. fusca in Ethiopia (59) and Ivory Coast (119). Delay in wetting larvae after diapause and access to water early in diapause had a 
deleterious effect on the larvae. The main factor enabling diapausing $B$. fusca larvae to survive adverse conditions appears to be efficient water conservation (194).

A combination of temperature and photoperiod played an important role in termination of diapause in B. fusca in South Africa, and water was important as a stimulus for morphogenesis following diapause (89). Long days accelerated termination of diapause in C. partellus, but under 16-h daylight, termination of diapause was faster than when under constant illumination. In contrast, temperature, relative humidity, and day length did not affect diapause of $C$. partellus and C. orichalcociliellus in Kenya (161). C. partellus collected in South Africa at $25^{\circ} 38^{\prime} \mathrm{S}, 27^{\circ} 47^{\prime} \mathrm{E}(90)$ is more affected by day length than the Kenyan population located near the equator. Kfir $(89,90)$ suggested that the right combination of day length and temperature could be used for breaking diapause to provide large numbers of insects for artificial infestations for plant-resistance trials. This requires only simple facilities and can save the large expense of keeping a continuous culture in the laboratory on artificial diet.

\section{DISPLACEMENT OF NATIVE STEM BORERS BY C. PARTELLUS}

The invasive stem borer, $C$. partellus, has proved to be a highly competitive colonizer in many of the areas it has invaded in eastern and southern Africa, often becoming the most injurious stem borer $(93,163)$ and displacing native species $(92,141)$. In coastal Kenya, there is evidence that $C$. partellus has partially displaced the indigenous stem borer, C. orichalcociliellus (130-132, 141). However, C. orichalcociliellus continues to be found at a relatively high frequency (10$30 \%$ of the borer complex), which suggests that the displacement of C. orichalcociliellus will not proceed to extirpation (228). Recent investigations have found that $C$. orichalcociliellus completed development in two native grasses, in which C. partellus could not develop (131), which may be one factor that allows their continued coexistence.

In addition to the work in the coastal area of Kenya, there is evidence of displacement of native stem borers in two other areas in Africa. In the Eastern Province of Kenya, $C$. partellus was present in the early 1980s but was less abundant than B. fusca (163). However, in the same area in the period 1996-1998, B. fusca was rare and $C$. partellus was dominant (183). Similarly, in the eastern Highveld region of South Africa, C. partellus partially displaced B. fusca over a period of seven years (92). The displacement was most evident in grain sorghum where the proportion of $C$. partellus in the total stem borer population increased from about $3 \%$ in 1986 to $91 \%$ in 1992 .

Several factors have been investigated that may be responsible for the competitive superiority of $C$. partellus over some native stem borers. $C$. partellus completes a generation in less time than $C$. orichalcociliellus $(101,131)$, which may result 
in a higher population growth rate. Moreover, $C$. partellus terminates diapause more rapidly than $C$. orichalcociliellus (130) or B. fusca (92), which may allow $C$. partellus to colonize host plants before the two native species at the beginning of growing seasons. Kfir (92) speculated that $B$. fusca avoids plants already infested by $C$. partellus, using odors associated with host plant feeding. Ofomata (129) showed that when equal numbers of $C$. partellus and $C$. orichalcociliellus infest the same maize, sorghum, or wild-sorghum plant, more C. partellus successfully completed development, suggesting superiority during direct competition. Finally, more neonate $C$. partellus larvae dispersed from the plant where they hatched, and they dispersed greater distances than $C$. orichalcociliellus, which may allow $C$. partellus to colonize more plants than the native borer (129).

\section{INDIGENOUS NATURAL ENEMIES}

\section{Parasitoids}

The indigenous parasitoids associated with African cereal stem borers have been treated in Polaszek (150). All stem borer parasitoids belong to either the Hymenoptera or Diptera. Their effectiveness in keeping stem borer populations below acceptable thresholds has been doubted by several authors $(93,142)$. However, no studies are yet available that examine the effect of the absence of parasitoids on stem borer populations. Recent investigations (R. Kfir, manuscript submitted) into the effects of removal or partial removal of parasitoids from stem borer-infested crops by applying insecticides showed that borer populations would double.

\section{Predators}

There have been a number of studies of the effectiveness of indigenous predators on several borer species in the past decade $(30,31,93,103,162)$. Virtually all studies have concluded that indigenous predators are not able to keep stem borer populations below economic injury levels $(31,162)$.

\section{Nematodes and Pathogens}

Available records of nematodes and pathogens infecting African cereal stem borers have been summarized recently (149). These authors also provided summaries for the study and identification of these agents. In doing so, they also concluded that in general nematodes and pathogens are not of great importance in regulating stem borer numbers.

Knowledge concerning viruses associated with African cereal stem borers has been reviewed (128). Iridoviruses, granulosis viruses, cytoplasmic viruses, and nuclear polyhedrosis viruses are known to attack and kill borer larvae in Africa, but no detailed studies have been conducted. 


\section{PEST STATUS AND YIELD LOSSES}

Feeding and stem tunneling by borer larvae on plants results in crop losses as a consequence of destruction of the growing point, early leaf senescence, interference with translocation of metabolites, and nutrients that result in malformation of the grain, stem breakage, plant stunting, lodging, and direct damage to ears $(18,33,36,94)$. Infestations by stem borers increase the incidence and severity of stalk rots (33).

In South Africa, estimated yield losses from $B$. fusca damage ranges between $10 \%$ and total loss $(24,106,109,206)$. Yield loss in maize by $B$. fusca was significantly correlated with leaf damage, but a higher correlation was observed with stem-boring damage (24). The estimated yield losses due to C. partellus in maize and sorghum exceed 50\% (153). A positive correlation between infestation level of $C$. partellus and yield loss was demonstrated (213). Trials in separate and mixed populations using artificial infestation on sorghum indicated that $C$. partellus was more injurious than B. fusca $(200,201)$. More damage by $C$. partellus was observed on long-season, grain-sorghum cultivars because of exposure over a longer period in the susceptible preflowering stages (199).

In Lesotho, seasonal variation in yield loss due to $B$. fusca damage on maize ranged between $0.4 \%$ and $36.6 \%$ (55). In Mozambique, larvae of third-generation C. partellus, the most important stem borer, were reported to infest $87 \%$ of cobs of late-planted maize and to severely damage $70 \%$ of grain (27). Infestations of up to $100 \%$ of plants, with considerable yield losses, have been recorded in the Maputo and Gaza Provinces (125), the Limpopo Valley (27), and in southern Mozambique (180).

In Zimbabwe, $C$. partellus caused yield loss of 50-60\% in sorghum (178). In maize, borer infestations range from $30 \%$ to $70 \%$ in fields of resource-poor farmers but are less than $30 \%$ in commercial farms where insecticides are used (177). In Tanzania (215) and Kenya (216), loss of about $12 \%$ maize grain for every $10 \%$ plants infested by $B$. fusca were reported. In Kenya, $18 \%$ yield losses were attributed to $C$. partellus and C. orichalcociliellus in maize (217) and $88 \%$ in sorghum owing to $C$. partellus (165).

Maximum stalk damage in maize and up to $80 \%$ grain yield loss in sorghum by $C$. partellus were observed in Kenya on 20-day-old crops, whereas similar infestations gave statistically nonsignificant losses when plants were infested at 60 days after emergence $(169,170)$. Similar observations were made in Uganda (184). In Tanzania, Jepson (81) reported 40-100\% sorghum plants infested by B. fusca, whereas in Ethiopia movement of $B$. fusca larvae into the base of the sorghum head resulted in undersized heads and grain loss of $15 \%$ (112).

Natural infestations by E. saccharina decreased maize yields by $16 \%, 15 \%$, and $28 \%$ in the dry season and first and second rainy seasons, respectively (33). Infested plots had significantly lower grain weight, indicating that $E$. saccharina damage to the stems affects grain filling. In Ghana, a positive relationship between the number 
of Sesamia sp. larvae and the extent of damage to maize stems, and a negative relationship between damage to maize stems and maize yield were shown (64). The calculated yield loss caused by Sesamia sp. to maize in the rain forest coastal, derived, and Guinea ecological zones were $27 \%, 15 \%, 18 \%$, and $14 \%$, respectively (64). In Burundi, insecticides and exclusion-cage trials indicated maize yield reductions of $12-15 \%$ by E. saccharina and $30-50 \%$ by B. fusca (121). In Burkina Faso and Niger, yield loss in sorghum by $C$. partellus and in millet by $C$. ignefusalis was estimated by using carbofuran to protect the crops and by infesting the crops at different growth stages. The highest grain yield was obtained when the crop was protected between 15 and 30 days after emergence; artificial infestation at 15 days after emergence resulted in the greatest damage. The infestation in unprotected sorghum plots was 60-62\% (188). Stem borer control in sorghum in the southern Guinea savanna of Nigeria, where S. calamistis predominates, improved yields by $16-19 \%$ (1), whereas in the northern Guinea savanna, where B. fusca predominates, yield losses of $49 \%$ in sorghum were reported (9). Yields of sprayed and unsprayed sorghum in 22 farmers' fields were studied in Nigeria, and a mean yield loss of $21 \%$ was determined (11). Yield loss in sorghum depends on the time of infestation (12). Sorghum infested by B. fusca before the booting stage suffered greater yield losses (110). Proportion of internodes bored in the lower part of the stalk had a more consistent negative correlation with grain yield than did proportion of stem tunneled (110). A recent study in Cameroon found that stem borers, primarily B. fusca, were responsible for a 9-g loss in grain yield per plant per borer and caused an $11 \%$ loss of plants owing to deadheart (43).

\section{MANAGEMENT}

\section{Utilization of Synthetic Sex Pheromones}

Pheromone-baited traps are useful devices for monitoring moth population levels of stem borers. Trap catches of male moths can provide useful information for the timing of insecticide applications $(154,208,210)$. Campion \& Nesbitt (42) reviewed the progress in the identification and the utilization of sex pheromones for stem borer monitoring and concluded that mass trapping is unlikely to provide satisfactory control but that mating disruption is more likely to be effective. Synthetic pheromone blends for Chilo suppressalis, C. sacchariphagus, Chilo indicus, Chilo auricilius and $C$. zacconius have shown satisfactory attractiveness to male moths in the field (25). Sex pheromones for B. fusca, C. partellus, S. calamistis, $S$. cretica, $S$. nonagrioides and $C$. ignefusalis have been identified and are available commercially $(195,225)$.

Several years of monitoring B. fusca using sex pheromone traps in South Africa $(95,96)$ revealed that the first flight resulting from moths emerging from hibernating borers peaked about the middle of November. The second flight, usually larger, peaked in the second half of February; a third flight, which occurred in 
Mpumalanga Province, peaked around the middle of April. No catches of moths were recorded during winter (June-September). Larval peaks of B. fusca in the field lagged about 4-6 weeks behind the corresponding moth flight peaks $(95,96)$. Omni-directional traps were superior to delta traps for quantitative and qualitative estimation of $B$. fusca moth populations $(95,96,207)$.

More research in trap design and correlations between moth catches and infestations in the field are required before trapping $C$. partellus can be used to determine economic threshold levels.

A slow-release pheromone formulation gave high levels of communication disruption in B. fusca when applied at $40 \mathrm{~g}$ a.i. $\mathrm{ha}^{-1}$ as 250 or 500 point sources $\mathrm{ha}^{-1}$ (49). This effect was observed to persist for at least 18 weeks and from release rate studies was predicted to last for 6 months. In field trials in Kenya, some reduction in damage levels was observed, indicating that mating disruption had occurred (49).

\section{Cultural Control}

Various methods of cultural control of stem borers in Africa have been reviewed $(102,113,164,166,196)$. It is the most relevant and economic method of stem borer control available for resource-poor farmers in Africa. Other control options are often not relevant because pesticides are too expensive or not available, resistant cultivars are not widely available, and biological control of stem borers is only partially successful. Cultural control is among the oldest traditional practices and normally cannot be used as a tactical means of control (52). Cultural control is considered the first line of defense against pests and includes techniques such as destruction of crop residues, intercropping, crop rotation, manipulation of planting dates, and tillage methods (196). The latter three agronomic practices can directly affect crop yield (52). Many cultural control practices are labor intensive, but they have little adverse effects on the environment and are readily available without extra investment in equipment.

However, an understanding of stem borers' behavior and the relationships with their respective crops are important for the development of efficient management strategies. The differences in the behavior of E. saccharina in South and eastern Africa provide an example of the importance of understanding pest behavior in making control decisions. In South Africa, larvae of E. saccharina mainly infest lower parts of sugarcane stalks. It is recommended that farmers cut stalks low and leave the tops, which are then cut off and left in the field. In East Africa, on the other hand, recommendations are to not leave tops of plants in fields because E. saccharina larvae largely occur in upper-plant parts, and these residues would house the carryover population (196).

Although cultural control options for stem borer management appear promising, most African farmers have not adopted them (126). Cultural control is severely constrained by the lack of management capabilities of farmers, especially in areas where farming communities lack the support of an adequate extension service (70). 


\section{Intercropping and Habitat Management}

Intercropping or mixed cropping has been widely practiced for centuries by smallscale farmers in Africa to reduce risk of crop failure, attain higher yields, and improve soil fertility $(155,196)$. Although some of these practices also lead to suppression of cereal stem borer populations, no studies have shown that farmers grow specific intercrops to exploit this effect. Many field studies have been conducted in Africa during the past two decades in an effort to identify the best crop combinations for reducing stem borer populations on cereal crops.

Studies in Kenya have concentrated both on the practice of intercropping cowpea with maize and sorghum and on the ways in which the developed systems could be adopted by small-scale farmers in eastern Africa $(16,138,148,162)$. Most concluded that intercropping reduced the incidence of stem borers. In West Africa, maize, millet, and sorghum intercropping were studied $(3,57,82)$. Maize/cassavaintercropping systems in Nigeria reduced by half larval numbers of $E$. saccharina, $B$. fusca, and S. calamistis populations (82). Many of these intercropping studies did not seek to determine the underlying mechanisms behind the effect of intercropping on stem borer population levels. Intercropping maize with cowpea was an effective way of reducing damage caused by $C$. partellus larvae migrating from neighboring plants $(146,148)$. This finding was confirmed by the reports that $30 \%$ of $C$. partellus oviposition in maize/sorghum/cowpea-intercropping systems was on cowpea, and the number of larvae reaching host plants from cowpea decreased with distance $(15,16)$.

A recent study from Kenya has reported the effectiveness of intercropping maize with the nonhost molasses grass, Melinis minutiflora $(98,99)$. In field trials, molasses grass showed no colonization by stem borers, and when used as an intercrop with maize, it significantly reduced stem borer infestation of the main crop. A significant increase in parasitism of stem borers by the larval parasitoid Cotesia sesamiae was also observed. Volatile agents produced by the molasses grass repelled stem borers but attracted foraging $C$. sesamiae. Female $C$. sesamiae were attracted to (E)-4, 8-dimethyl-1,3,7-nonatriene, one of the volatile components released by intact molasses grass. Nonatriene has been implicated as an SOS signal for recruiting predators and parasitoids and is also produced by stem borer-damaged maize plants. Intact plants with an inherent ability to release such attractive stimuli could be used in new crop-protection strategies. As well as serving as an effective cover crop, the molasses grass provides good fodder for livestock. The grass is now being tested in on-farm trials in Kenya to control stem borers on maize (100).

Another useful diversionary tactic for stem borer control is planting an outer encircling row of some highly preferred host to act as a trap plant. Napier grass, Pennisetum purpureum, and Sudan grass, Sorghum vulgare sudanense, common fodder plants in Africa, were reported from Kenya to provide natural control to stem borers by acting as trap plants $(99,100)$. Although the stem borers oviposit heavily on the attractive Napier grass, only few larvae complete their life cycles (76). Napier grass has its own defense mechanism against crop borers. When the 
larvae enter the stem, the plant produces a gummy substance that causes the death of the pest (76). In on-farm trials in Kenya, planting Napier grass around maize fields significantly increases crop yields by reducing the stem borer population in maize. Sudan grass, also a fodder grass, provided natural control of stem borers by acting as a trap plant and as a reservoir for its natural enemies (99). In field trials conducted in Kenya, planting Sudan grass around maize fields decreased stem borer infestation on maize and thus increased crop yield (99). Planting Sudan grass around maize field also increased efficiency of natural enemies.

For the control of stem borers in resource-poor, maize farming systems in eastern Africa, novel habitat-management strategies have been developed using "push-pull" or stimulo-deterrent diversionary tactics (100). These strategies involve combined use of intercropping and trap crop systems. Stem borers are trapped on highly susceptible trap plants (pull) and are driven away from the maize crop by repellent intercrops (push). The plants, which are used as trap or repellent plants in a push-pull strategy, are Napier grass, Sudan grass, molasses grass, and silverleaf desmodium, Desmodium uncinatum. Napier grass and Sudan grass are used as trap plants, whereas molasses grass and silverleaf desmodium repel ovipositing stem borers. Molasses grass, when intercropped with maize, not only reduced infestation of the maize by stem borers but also increased stem borer parasitism by a natural enemy, C. sesamiae (98). All four plants are of economic importance to farmers in eastern Africa as livestock fodder.

The economic gain from the use of intercrops depends on the balance between a lowered cost of control of stem borers and the increased cost of maintaining an intercropped field, along with any decrease in yield of the main crop from greater plant competition. Net profit can be increased if the intercrop favorably changes the balance between income and costs. Economic data assessing the financial returns as well as the biological effects are therefore most useful in making decisions on the use of intercrops and trap plants for stem borer control.

\section{Management of Crop Residues}

Crop residues are important for carrying over stem borer larval populations from one growing season to the next. In Nigeria, larvae of B. fusca, E. saccharina, and $S$. calamistis were found in crop residues below the soil surface, and higher incidences of these borers were observed in no-tillage plots (82). In Kenya, C. orichalcociliellus, C. partellus, E. saccharina, and S. calamistis were observed in stalks after harvest $(163,217)$. In Ethiopia, a considerable proportion of $B$. fusca larvae survive in stubble (223). In Uganda, untreated crop residues were often used to mulch the next crop (115). Under these conditions, borers from the old stalks constantly infested the newly planted crops.

An effective control option would be to reduce the first generation of adult population by destroying the larvae in old stalks $(78,84,97,192)$. Ploughing in order to bury maize stubble was an effective control measure used early in the twentieth century in South Africa to control B. fusca (106). In Zimbabwe, it was 
observed that $B$. fusca moths emerging through $5 \mathrm{~cm}$ of soil were crippled and that deeper burial of the stalks under $10-15 \mathrm{~cm}$ of soil ensured that no adult moths emerged (115).

Tillage practices are viable options for B. fusca and C. partellus control in South Africa, where large areas of maize or sorghum are planted and between 90,000 and 226,000 larvae overwinter per hectare (84). Slashing maize and sorghum stubble destroyed $70 \%$ of $C$. partellus and B. fusca populations, and additional ploughing and disking destroyed a further $24 \%$ of the pest population in sorghum and $19 \%$ in maize $(84,97)$. Tillage may reduce borer populations through mechanical damage either by burying them deeply into the soil or by breaking the stems and exposing the larvae to adverse weather conditions $(8,68)$, as well as birds, rodents, ants, spiders, and other natural enemies $(84,87,97,167)$. For these cultural control measures to be effective, the cooperation of farmers in a region is required because moths emerging from untreated fields can infest adjacent crops (88). Currently this system is not widely practiced in South Africa because of the advent of minimum tillage and the importance of winter grazing of maize to beef farmers $(88,95)$.

In rural Africa, farmers often use dry stems of maize, sorghum, and millet for building houses and fences, as fuel, bedding for livestock, boundaries of terraces on slopes, and as stakes $(68,156,161)$. Farmers normally stack dry stalks in the field where they are kept until commencement of rains before being taken to villages, thus creating a reservoir for infestation in the following season (196). To solve this problem, early cutting of stalks and horizontal placement on the soil surface has been recommended. This was observed to cause mortality of $97 \%$ of stem borers in maize and $100 \%$ in sorghum in Ethiopia (58) and to reduce the residual population of borers in millet from $16 \%$ in uncut stems to 3\% (227). The high level of mortalities of $C$. partellus, $C$. orichalcociliellus, and S. calamistis in horizontally placed stalks was ascribed to the effects of sun and heat, more specifically, the reaching of the thermal threshold for survival (147). On the other hand, in Nigeria, the control of S. calamistis, B. fusca, C. ignefusalis, and E. saccharina on maize by removing stalks and stubble after harvest did not reduce stem borer populations significantly apparently because of migration of adults into the crops (2).

Control of B. fusca and $C$. partellus by burning old stalks and other crop residues immediately after harvest has been recommended $(8,68,80,192)$. In Tanzania, almost complete eradication of $C$. partellus on maize and sorghum was achieved by burning (53). About $95 \%$ of farmers in Nigeria kept sorghum stalks and did not follow the recommended practice of burning them after harvest (4). As a compromise, partial burning was recommended while the leaves are dry but the stalks are not $(4,8)$. Heat generated from the burning leaves kills up to $95 \%$ of larvae and at the same time cures the stalks, making them stronger as building materials and more resistant to termite attack $(4,12)$. Crop residues are the only organic matter added into soils in many small-scale African farms. Burning crop residues can create problems in farms where the organic content of soils is low and soil erosion from wind and rain is severe (196). 


\section{Manipulation of Sowing Dates and Densities}

Growing crops when the pest is least abundant ensures that the most susceptible stage of crop growth does not coincide with periods of peak moth activity. In Kenya, an attempt to legislate this principle was made in order to control B. fusca on maize during the 1920s and 1930s $(17,221)$ with the objective to restrict planting maize to the February-May period, when infestation is normally low. There is no available information on the effectiveness of these measures, and the last implementation of this legislation was in 1937-1938 (72).

In West Africa, early planting reduced B. fusca and S. calamistis infestations (1). Several workers have reported more damage by stem borers to late-planted maize than to early plantings, e.g., in Benin (175), Burundi (121), Cameroon (22), Ghana $(62,64)$, Nigeria $(5,44,68)$, and Zaire $(77)$. Thus, in some areas of West Africa farmers do not plant maize during the second season because of severe infestations. This affects the borer populations in the rain forest zone where alternative wild host plants in the dry season are scarce (34). This strategy is also desirable in the semi-arid tropics, where rainfall is variable and unpredictable; late sowing is not desirable because the yield of late sown crops is low, even if free from stem borers (166).

In the Highveld region of South Africa, the second-generation population $B$. fusca is larger and can cause more damage than the first generation (211). The best strategy to reduce damage would be to plant early in the growing season. Similar observations were made in Lesotho (55), Zimbabwe (179), and Ethiopia where second-generation larvae caused crop losses of 22.5-100\% compared with $0-22.6 \%$ by first generation (60).

In the lower elevations of South Africa, it is recommended that sorghum be planted after mid-October to avoid infestation from the first moth peak of C. partellus (204). In Tanzania, Swaine (185) found that maize planted early in the season was more infested by B. fusca than maize sown later. In Malawi, planting date influenced infestation levels of $B$. fusca and $C$. partellus on sorghum; however, the choice of optimum sowing date depends on the sorghum cultivar (111). In contrast, in the Sahelian region, manipulating the planting dates of millet is not a good method to reduce infestation by $C$. ignefusalis (227).

Sowing density may affect the crop and its pest population, as well as the behavior of the pest in searching for food or an oviposition site (102). Young C. partellus migrate from their hatching site to the funnel leaves or to other plants within the vicinity. During this migration, up to $100 \%$ mortality may occur (108). The lowest incidence of deadheart caused by B. fusca occurred at the lowest plant density in sorghum in South Africa (198) and maize in Nigeria (134). A reduction in row width increased the number of larvae able to reach adjacent plant rows through migration, and this in turn resulted in more damaged plants (211). B. fusca larvae migrate up to $2.4 \mathrm{~m}$ (68) and at a $0.9 \mathrm{~m}$ interrow spacing, which is common in commercial agriculture; they migrated over 4 rows from the hatching site (211). In Ivory Coast it was suggested that maize be grown with larger interrow 
spacing rather than with reduced plant number within the row to reduce $B$. fusc $a$ and E. saccharina damage (118). Studies on $C$. partellus in maize planted at different densities (56) and on C. ignefusalis in millet (57) showed no significant difference in oviposition or borer incidence.

In subsistence farming systems in Africa where farmers normally intercrop cereals with other crops and lack of water is a major constraint, manipulation of sowing dates and management of plant densities is not always practical as farmers often plant after first rains (196). Farmers' choice of sowing dates is affected by many constraints, and it is unlikely that a change in sowing date alone will result in higher sustainable yields (126).

\section{Fertilizer}

Fertilizing crops can increase infestation and survival of borers through an increase in the nitrogen content of plants (196). In Nigeria, damage to rice by M. separatella increased with the application of fertilizer (191), and in South Africa sorghum plants without fertilizers were less preferred for oviposition by C. partellus (197), but no differences were observed in oviposition by B. fusca (212). In South Africa, where $E$. saccharina is a problem on sugarcane, a reduction in nitrogen-fertilization rate from $50 \mathrm{~kg}$ per hectare to $30 \mathrm{~kg}$ per hectare is recommended (158). An increase in the survival of $S$. calamistis larvae and acceleration in larval development with increased nitrogen content of maize was observed, and this may result in an increase in the number of generations per year (171).

Nitrogen fertilization enhances borer development as well as the plant's tolerance to borer attack. Yield losses decreased linearly from $20 \%$ with no fertilizer to $11 \%$ with $120 \mathrm{~kg}$ of nitrogen per hectare (172). Ajayi (10) observed that time of nitrogen application influenced incidence of $C$. ignefusalis on millet and suggested that the manipulation of time of nitrogen application may achieve a compromise between using low levels of nitrogen for low stem borer infestation and using high levels for better yields.

\section{Host Plant Resistance}

Host plant resistance as an approach to pest management in gramineous crops confers many advantages (34). Resistant crop varieties provide an inherent control that involves no environmental problems, and they are generally compatible with other insect-control methods. The cultivation of resistant crop plants is not subject to the vagaries of weather as are chemical-control measures, and in certain circumstances it is the only effective means of control. Resistant varieties control even a low pest density, whereas insecticide use is justifiable only when the density reaches the economic injury level. Efforts are underway in Africa to identify sources of stem borer resistance in cereal crops, but high levels of resistance have not been found. 


\section{Breeding for Resistance}

Efforts have been made to incorporate resistance of maize and sorghum to C. partellus into a good agronomic background during the past two decades $(6,7,14)$, and many genotypes are already in national yield trials. Resistant lines/ hybrids with good general combining ability have been identified (167). Several hybrid sorghums bred in South Africa exhibited greatest tolerance to stem borer damage and therefore suffered low yield losses (202).

\section{Biological Control}

Over the past 60 years, there have been numerous attempts to introduce exotic parasitoids into Africa and the Indian Ocean Islands for biological control of exotic and native stem borers, but only a few species have established (Table 2). On the mainland, only $C$. flavipes has established.

In 1993, the gregarious larval endoparasitoid, C. flavipes, was introduced into Kenya from Pakistan for biological control of $C$. partellus. Releases were made in the southern coastal area of Kenya (144), and the parasitoid was recovered during the season of release from $C$. partellus and two native stem borers, C. orichalcociliellus and S. calamistis (143). In 1994 only one stem borer parasitized by $C$. flavipes was found despite intensive sampling. In 1995 and 1996 a few recoveries were made but parasitism remained low (143). In 1997 the number of recoveries increased dramatically and parasitism at 30 sites averaged about $6 \%$. Parasitism continued to increase during the next two years with average parasitism of about 13\% in 1999 (228). Surveys in other maizegrowing areas of Kenya showed that $C$. flavipes was present in the Eastern Province (183) and in the area bordering Lake Victoria in western Kenya (139). In the Eastern Province, C. flavipes was found in low densities in 1996 and then released at three sites in 1997. Parasitism during the season following the releases was about $14 \%$ (183). C. flavipes was never intentionally released in western Kenya, but Omwega et al. (139) speculated that the establishment was the result of insects that escaped from a local laboratory colony in 1992. However, parasitism in western Kenya has not increased to the levels observed in coastal Kenya or the Eastern Province (133). In western Kenya, four stem borers are common in maize, C. partellus, S. calamistis, B. fusca, and E. saccharina (163), all of which are attractive and acceptable hosts for $C$. flavipes. Two of which, B. fusca and E. saccharina, are not suitable for its development $(123,143)$. Overholt $(141)$ suggested that the presence of acceptable but unsuitable hosts in an area would create a sink for $C$. flavipes eggs and depress population growth.

The impact of $C$. flavipes on stem borer populations in coastal Kenya was recently investigated (228). A ratio-dependent, host-parasitoid model was used to estimate the stem borer density with and without the parasitoid. A reduction of 1.11.6 stem borers/plant, equivalent to a $32-55 \%$ decrease in the stem borer density, 


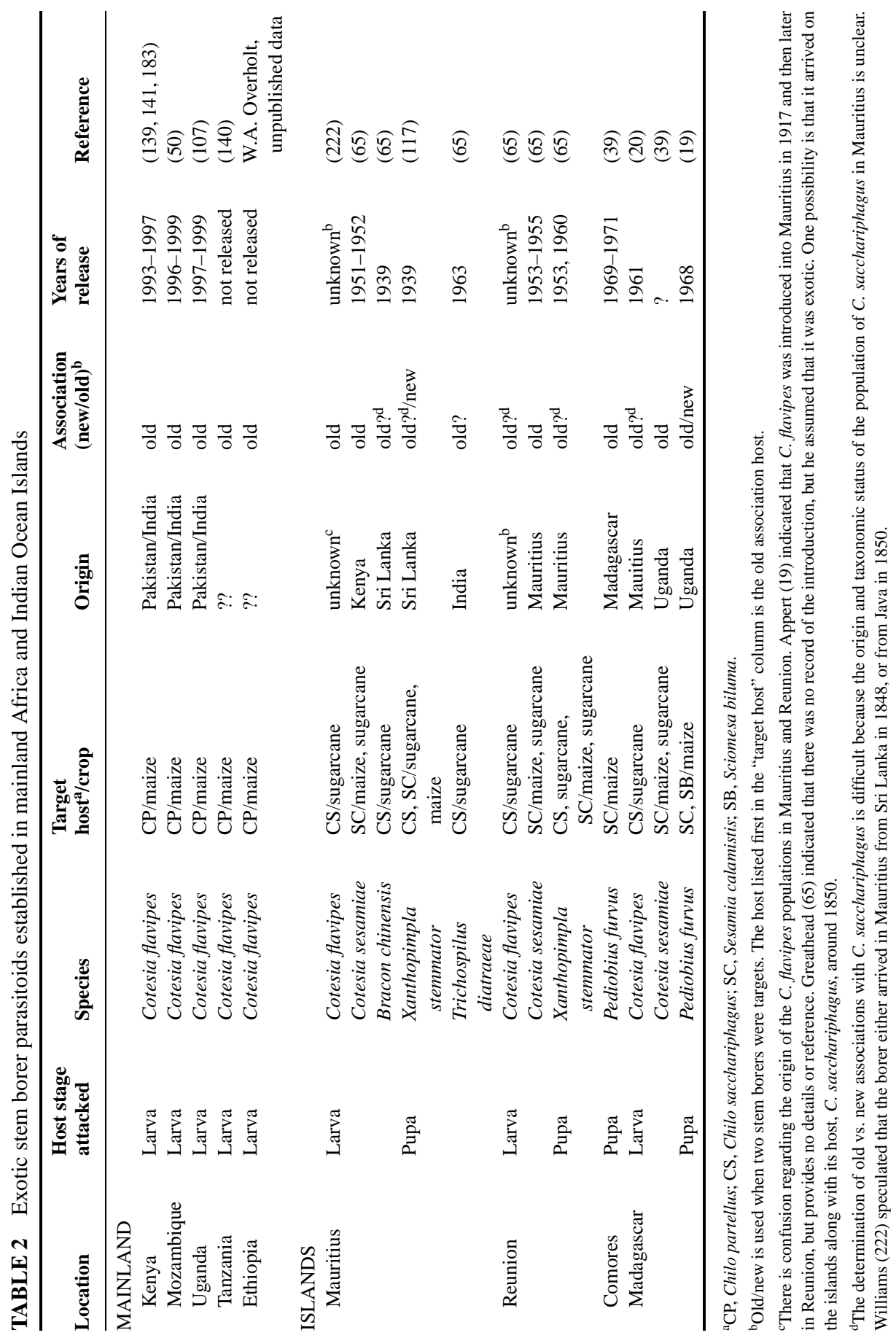


was shown. As there is not yet any evidence that the $C$. flavipes density has reached an equilibrium, it may continue to increase and provide greater suppression of stem borers in the future.

In addition to the work conducted in Kenya, a survey in 1995 in northern and central Tanzania recovered C. flavipes at two locations near Lake Victoria in an area bordering southwestern Kenya (140). Based on surveys conducted prior to 1994, and on electrophoretic evidence, it was concluded that the most likely explanation was that $C$. flavipes moved into Tanzania from Kenya (140).

Releases of $C$. flavipes were made in Mozambique in 1996 (50) and in Uganda and Somalia in 1997 (141). Recoveries in Mozambique in 1999 indicated that the parasitoid had established but parasitism was low. In Uganda, one year after the release of $C$. flavipes, it had become the most common parasitoid of a complex of four stem borers, and parasitism averaged about 20\% (107). No postrelease surveys have been conducted in Somalia, but recoveries in neighboring Ethiopia, where the parasitoid was never released (W.A. Overholt, unpublished information), strongly suggest that the parasitoid established in Somalia and moved into Ethiopia. Releases in Zimbabwe, Zambia, Zanzibar, and Malawi were made in 1998-1999, but to date, establishment has not been confirmed (W.A. Overholt, unpublished information).

Examination of the failures and successes in establishing exotic parasitoids suggests several factors that may be related to establishment. The success rate on the Indian Ocean Islands has clearly been much higher than on mainland Africa, where the only confirmed establishment has been $C$. flavipes. The higher rate of establishment on islands is true not only for stem borer parasitoids but for natural enemies introduced against other pests as well. Greathead (65) reviewed classical biological control in Africa and suggested that the greater success on the Indian Ocean Islands could be explained by the theory of island biogeography (104). Species are packed more tightly and are more specialized on continents than on islands, and thus, specialist parasitoids encounter less resistance (competition) when colonizing islands.

The geographic factor of islands versus the mainland is confounded with a second, potentially influential factor. The major emphasis of the stem borer biological control activities on the Indian Ocean Islands was against $C$. sacchariphagus in a sugarcane ecosystem, whereas in mainland Africa the work has been directed mostly in maize and sugarcane, with lesser effort in rice. The only successes in maize have been the introductions of Pediobius furvus and $C$. sesamiae from mainland Africa to Indian Ocean Islands for control of $S$. calamistis and the recent establishment of $C$. flavipes in Kenya.

Ecological differences between sugarcane and maize ecosystems may influence establishment. Sugarcane is grown throughout the year and thus provides a fairly stable habitat. In contrast, the maize ecosystem is short-lived, providing a suitable habitat for stem borers and their natural enemies for only two or three months. Brenière et al. (39) suggested that a lack of habitat stability on the island of Ngazidja (Comores) was the reason for several failures of the establish parasitoids against 
C. partellus in maize. A review of success rates in biological control programs in different categories of habitat stability supports the hypothesis that the chance of establishment increases with an increase in habitat stability (66). However, the lack of success in South Africa against E. saccharina in sugarcane, despite 15 years of intense effort (47), suggests that a semiperennial sugarcane habitat alone is not sufficient for the establishment of parasitoids. Conlong (47) points out that climate compatibility is also a major factor that influences establishment and suggests that the temperate climate of South Africa has not been conducive for the establishment of parasitoids from tropical and subtropical regions. Similar explanations have been given for the lack of success in biological control of C. partellus in South African maize $(91,181)$.

Old host/parasitoid associations more likely result in establishment than do new associations. All establishments on the Indian Ocean Islands and the only confirmed establishment on mainland Africa included at least one old-association relationship (see footnote $\mathrm{c}$ to Table 2). The behavioral and physiological compatibility of old-association parasitoids and their hosts are implicit, whereas in new associations compatibility cannot be assumed (220). The greater success of old associations supports the contention of several authors $(66,67,214)$. However, as stem borers typically occur in complexes, at times including both exotic and native pests, introduced parasitoids will often encounter both old- and newassociation hosts when colonizing a new area. The probability of establishment and the level of suppression of the stem borer complex may depend not only on the old host/parasitoid relationship(s) but also on the compatibility of the new relationships.

Finally, a notable aspect of the introduction of stem borer parasitoids into Africa has been the number of times Cotesia spp. have established as compared with other parasitoids. Worldwide, C. flavipes has been introduced into more than 40 countries in the tropics and subtropics for biological control of crambid stem borers, primarily those in the genera Chilo and Diatraea (151). In Mauritius, parasitism of 4-50\% of larvae of the introduced stem borer, Chilo sacchariphagous, has been reported (152). In Madagascar, where C. flavipes was introduced in 1960, parasitism of $60 \%$ of C. sacchariphagous larvae was reported (28). The success of C. sesamiae is limited to its establishment on Mauritius, Reunion, and Madagascar (Table 2), where it was introduced against $S$. calamistis.

Several factors could be responsible for the success of the two Cotesia spp. In their areas of endemism, the Cotesia spp. parasitoids often attack more than one species of crambid and/or noctuid stem borers $(26,63,114,116,122,173)$. A parasitoid that exploits more than one of the hosts in the target habitat may better colonize a new area than a parasitoid with a narrow host range owing to a more constant availability of hosts and a lack of population growth depression due to wasting eggs in attractive but unsuitable hosts.

Another factor that may predispose $C$. flavipes and $C$. sesamiae to establish is gregarious reproduction. Hopper \& Roush (75) suggested that an Allee effect might explain many failures to establish natural enemies for biological control. 
They speculated that low densities, which may occur after the release of an arrhenotokus parasitoid, might decrease chances of mate finding, thus leading to possible extinction. However, $C$. flavipes and $C$. sesamiae mate with their siblings before dispersal $(21,144,157)$, and thus Allee effects will not influence establishment.

A high host-searching ability has been suggested as a factor involved in the success of $C$. flavipes. Even at low host densities, C. flavipes successfully located stem borer hosts (219). The high host-searching success of $C$. flavipes may in part be due to its behavior of entering tunnels in plant stems to attack stem borer larvae (182). Many larval parasitoids of stem borers remain on the outside of the stem and attack their hosts by drilling, or locating breaches through the stem, with their ovipositor (182). This strategy may be effective for attacking stem borers in small-stemmed wild grasses, but in relatively larger-stemmed cultivated grasses, the length of the ovipositor may limit the number of hosts susceptible to attack (74).

\section{ACKNOWLEDGMENTS}

Thanks to the Illinois Natural History Survey, Department of Entomology, Department of Natural Resources and Environmental Sciences, and the Office of International Programs of the University of Illinois for support during a sabbatical leave at INHS by the senior author while this article was prepared. Thanks to Tharina Bird and Kerstin Krüger (ARC-PPRI) for help in sorting out the references. R. Wiedenmann (INHS) constructively commented on an early draft of the manuscript.

\section{Visit the Annual Reviews home page at www.AnnualReviews.org}

\section{LITERATURE CITED}

1. Abu JF. 1986. Biology and Control of the Insect Pests of Sorghum in the Southern Guinea Savanna Zone of Nigeria. Zaria, Nigeria: Inst. Agric. Res. Samaru. 23 pp.

2. Adenuga AO. 1977. Comparative methods and the economics of control of stem borers (Lepidoptera: Noctuidae and Pyralidae) on local maize, Zea mays. Proc. Ann. Conf. Nigerian Soc. Plant Prot. (NSPP), 7th, pp. 52-53. Occasional Publ., Nigerian Soc. Plant Prot.

3. Adesiyun AA. 1983. Some effects of intercropping sorghum, millet and maize on infestation by lepidopterous stalk-borers, particularly Busseola fusca. Insect Sci. Appl. 4:387-91

4. Adesiyun AA, Ajayi O. 1980. Control of the sorghum stem borer, Busseola fusca, by partial burning of the stalks. Trop. Pest Manag. 26:113-17

5. Adeyemi SAO, Donelly J, Odetoyinbo JA. 1966. Studies on chemical control of stem borers of maize. Nigerian Agric. J. 3:61-66

6. Ajala SO. 1993. Population cross diallel among maize genotypes with varying levels of resistance to the spotted stem borer Chilo partellus (Swinhoe). Maydica 38:39-45

7. Ajala SO, Saxena KN, Chiliswa P. 1995. Selection in maize (Zea mays L.) for resistance to the spotted stem borer (Chilo partellus (Swinhoe)). Maydica 40:13740 
8. Ajayi O. 1978. Control of sorghum, millet and wheat insect pests. Samaru Conf. Inst. Agric. Res., Ahmadu Bello Univ., Zaria, Nigeria

9. Ajayi O. 1987. Insecticidal control of the sorghum stem borer. Cereals Res. Programme. Crop. Scheme Rep. Inst. Agric. Res., Samaru, Zaria, Nigeria

10. Ajayi O. 1990. Possibilities for integrated control of the millet stem borer, Acigona ignefusalis Hampson (Lepidoptera: Pyralidae), in Nigeria. Insect Sci. Appl. 11:10917

11. Ajayi O. 1991. Yield reduction in sorghum caused by Busseola fusca (Fuller) and Sesamia calamistis Hampson. Conf. Afr. Assoc. Insect Sci., 9th, Accra, Ghana

12. Ajayi O. 1998. Sorghum: West Africa. See Ref. 150, pp. 39-45

13. Akinsola EA, Agyen-Sampong M. 1984. The ecology, bionomics and control of rice stem-borers in West Africa. Insect Sci. Appl. 5:69-77

14. Ampofo JKO, Dabrowski ZT, Omolo EO. 1986. Registration of germplasm lines of maize. Crop Sci. 26:650

15. Ampong-Nyarko K, Seshu Reddy KV, Nyang' or RA, Saxena KN. 1994. Reduction of pest attack on sorghum and cowpea by intercropping. Entomol. Exp. Appl. 70:179-84

16. Ampong-Nyarko K, Seshu Reddy KV, Saxena KN. 1994. Chilo partellus (Swinhoe) (Lep., Pyralidae) oviposition on nonhosts: a mechanism for reduced pest incidence in intercropping. Acta Ecol. 15: 469-74

17. Anderson TJ. 1929. Control of maize stalk borers. Bull. Dep. Agric. Kenya, $7 F$. $5 \mathrm{pp}$.

18. Appert J. 1970. Insects Harmful to Maize in Africa and Madagascar. Madagascar: Madagascar Inst. Agron. Res. 71 pp.

19. Appert J. 1973. Entomofaune parasitaire des foreurs des graminées à Madagascar. Entomophaga 18:77

20. Appert J, Betbeder-Matibet M, Ranaivosoa H. 1969. Vingt années de lutte biologique à Madagascar. Agron. Trop. 24:555-72

21. Arakaki N, Gahana Y. 1986. Emergence pattern and mating behavior of Apanteles flavipes (Cameron) (Hymenoptera: Braconidae). Appl. Entomol. Zool. 21:382-88

22. Aroga R. 1988. Entomologie des cereales. Rapport d'activities; années 1987 et 1988. Cameroun Natl. Cereals Res. Ext. Proj.

23. Atkinson PR. 1979. Distribution and natural hosts of Eldana saccharina Walker in Natal, its oviposition sites and feeding patterns. Proc. S. Afr. Sugar Tech. Assoc. 53:111-15

24. Barrow MR. 1987. The effect of first generation maize stalkborer, Busseola fusca (Fuller) (Lepidoptera: Noctuidae), on yield of different maize genotypes. $J$. Entomol. Soc. S. Afr. 50:291-98

25. Beevor PS, David H, Jones OT. 1990. Female sex pheromones of Chilo spp. (Lepidoptera: Pyralidae) and their development in pest control applications. Insect Sci. Appl. 11:787-94

26. Beg MN, Inayatullah C. 1980 . Studies on Apanteles flavipes a parasite of graminaceous borers. Pak. J. Agric. Res. 1:50-53

27. Berger A. 1981. Biological control of the spotted stalkborer, Chilo partellus (Swinhoe) in maize by using the bacteria Bacillus thuringiensis. Rep. Inst. Nacional de Investigaáao Agronomica. Proj. UNDP/FAO MOZ/75/009, Maputo, Mozambique

28. Betbeder-Matibet M, Malinge P. 1968. Un succès de la lutte biologique: contrôle de Proceras sacchariphagus Boj. Borer ponctué de la canne à sucre à Madagascar par un parasite introduit: Apanteles flavipes Cam. Agron. Trop. 22:1196-220

29. Bleszynsky S. 1970. A revision of the world species of Chilo Zincken (Lepidoptera: Pyralidae). Bull. Br. Mus. (Nat. Hist.) Entomol. 25:101-95

30. Bonhof MJ. 1998. Predators. See Ref. 150, pp. 295-307

31. Bonhof MJ. 2000. The impact of predators 
on maize stem borers in coastal Kenya. $\mathrm{PhD}$ thesis. Wageningen Univ., Neth. 181 pp.

32. Bosque-Pérez NA, Mareck JH. 1990. Distribution and species composition of lepidopterous maize borers in southern $\mathrm{Ni}$ geria. Bull. Entomol. Res. 80:363-68

33. Bosque-Pérez NA, Mareck JH. 1991. Effect of the stem borer Eldana saccharina (Lepidoptera: Pyralidae) on the yield of maize. Bull. Entomol. Res. 81:243-47

34. Bosque-Pérez NA, Schulthess F. 1998. Maize: West and Central Africa. See Ref. 150, pp. 11-27

35. Deleted in proof

36. Brenière J. 1971. Les problèmes des lépidoptères foreurs des graminées en Afrique de l'Ouest. Ann.Zool. Ecol. Anim. 3:287-96

37. Brenière J. 1976. Reconnaissance des principaux lépidoptères du riz de l'Afrique de l'Ouest. Agron. Trop. 1:212-31

38. Brenière J, Bordat D. 1982. Intérêt et difficultés de la lutte biologique par introduction d'entomophages - cas des foreurs du riz en Afrique. Agron. Trop. 37:203-6

39. Brenière $\mathrm{J}$, Bordat $\mathrm{D}$, Vercambre $\mathrm{B}$, Hamza H, Renand M. 1985. Les opérations de lutte biologique contre le foreur du mais Chilo partellus (Swinhoe), Lepidoptera, dans l'Ile de Ngazidja. Agron. Trop. 40:157-66

40. Brenière J, Rodriguez H, Ranaivosoa H. 1962. Un ennemi de riz à Madagascar, Maliarpha separatella Rag. ou boreur blanc. Agron. Trop. 17:223-302

41. CABI. 1989. Chilo partellus (Swinh.). Distribution Maps of Pests. Series A (Agriculture). No. 184. London: Int. Inst. Entomol.

42. Campion DG, Nesbitt BF. 1983. The utilization of sex pheromones for the control of stem-borers. Insect Sci. Appl. 4:191-97

43. Cardwell KF, Schulthess F, Ndemah R, Ngoko Z. 1997. A systems approach to assess crop health and maize yield losses due to pests and diseases in Cameroon. Agric. Ecosyst. Environ. 65:33-47
44. Carter AO. 1985. An evaluation of the importance of stem borers and their control on maize grown in south eastern Nigeria MSc thesis. Univ. Reading, UK. 57 pp.

45. Conlong DE. 1990. A study of pestparasitoid relationships in natural habitats: an aid towards the biological control of Eldana saccharina (Lepidoptera: Pyralidae) in sugarcane. Proc. S. Afr. Sugar Tech. Assoc. 64:111-15

46. Deleted in proof

47. Conlong DE. 1997. Biological control of Eldana saccharina Walker in South African sugarcane: constraints identified from 15 years of research. Insect Sci. Appl. 17:69-78

48. Cook M. 1997. Revision of the genus Maliarpha Ragonot (Lepidoptera: Pyralidae), based on adult morphology with a description of three new species. Bull. Entomol. Res. 87:25-36

49. Critchley BR, Hall DR, Farman DI, McVeigh LJ, Mulaa MA, Kalama P. 1997. Monitoring and mating disruption of the maize stalkborer, Busseola fusca, in Kenya with pheromones. Crop Prot. 16:541-48

50. Cugala D, Overholt WA, Giga D, Santos L. 1999. Performance of Cotesia sesamiae and Cotesia flavipes (Hymenoptera: Braconidae) as biological control agents against cereal stemborers in Mozambique. Afr. Crop Sci. J. 7:497-502

51. Delobel A. 1975. Chilo orichalcociliellus Strand (Lepidoptera: Pyralidae), fôreur des tiges du sorgho et du mais à Madagascar II. Premières données biologiques. ORSTOM Sér Biol. 10:11-16

52. Dent D. 1991. Insect Pest Management. Wallingford, UK: CABI. 604 pp.

53. Duerden JC. 1953. Stem borers of cereal crops at Kongwa, Tanganyika, 1950-52. East Afr. Agric. For. J. 19:105-19

54. Du Plessis C, Lea HAF. 1943. The maize stalk borer, Calamistis fusca (Hmps). Bull. Dep. Agric. For. Union S. Afr. 238. $51 \mathrm{pp}$.

55. Ebenebe AA, Van den Berg J, Van den 
Linde TC. 1999. Effect of planting date of maize on damage and yield loss caused by the stalk borer, Busseola fusca (Fuller) (Lepidoptera: Noctuidae) in Lesotho. $S$. Afr. J. Plant Soil 16:180-85

56. Firempong S. 1988. The effect of maize cultivar and planting density on C. partellus oviposition in the field. ICIPE 15th Annu. Rep. 1987

57. Gahukar RT. 1989. Pest and disease incidence in pearl millet under different plant density and intercropping patterns. Agric. Ecosyst. Environ. 26:69-74

58. Gebre-Amlak A. 1988. Survival of maize stalk borer, Busseola fusca (Fuller) in crop residues in Ethiopia. Crop Prot. 7:18385

59. Gebre-Amlak A. 1989. Termination of diapause in the maize stalk borer, Busseola fusca (Fuller) (Lep., Noctuidae), in Awassa, southern Ethiopia. J. Appl. Entomol. 107:160-65

60. Gebre-Amlak A, Sigvald R, Petterson J. 1989. The relationship between sowing date, infestation and damage by the maize stalkborer, Busseola fusca (Noctuidae), on maize in Awassa, Ethiopia. Trop. Pest Manag. 35:143-45

61. Girling DJ. 1978. The distribution and biology of Eldana saccharina Walker (Lepidoptera: Pyralidae) and its relationship to other stemborers in Uganda. Bull. Entomol. Res. 68:471-88

62. Girling DJ. 1980. Eldana saccharina as a crop pest in Ghana. Trop. Pest Manag. 26:152-56

63. Goraya AA, Mushtaque M, Attique MR. 1982. Suitability of Apanteles flavipes (Cameron) (Hym.: Braconidae) as a biocontrol agent for graminaceous stemborers in Pakistan. Proc. Ann. Conv. Pak. Soc. Sugar Tech., 18th, Rawalpindi, pp. 177-82. Lahore: Pakistan Soc. Sugarcane Technol.

64. Gounou S, Schulthess F, Shanower T, Hammond WNO, Braima H, et al. 1993. Stem and Ear Borers of Maize in Ghana. Plant Health Manag. Div., Res. Monogr.
3. Ibadan, Nigeria: Int. Inst. Trop. Agric. $84 \mathrm{pp}$.

65. Greathead DJ. 1971. A Review of Biological Control in the Ethiopian Region. Tech. Commun. No. 5. Commonw. Inst. Biol. Control. Farnham R., Engl: Commonw. Agric. Bur. 162 pp.

66. Hall RW, Ehler LE. 1979. Rate of establishment on natural enemies in classical biological control. Bull. Entomol. Soc. Am. 25:280-82

67. Hall RW, Ehler LE, Bisabri-Ershadi B. 1980. Rate of success in classical biological control of arthropods. Bull. Entomol. Soc. Am. 26:111-14

68. Harris KM. 1962. Lepidopterous stem borers of cereals in Nigeria. Bull. Entomol. Res. 53:139-71

69. Harris KM. 1989. Biology of sorghum stem borers. See Ref. 70, pp. 63-71

70. Harris KM. 1989. Recent advances in sorghum and pearl millet stem borer research. In Int. Workshop Sorghum Stem Borers, Patancheru, 1987, ed. KF Nwanze, pp. 9-16. Patancheru, India: ICRISAT

71. Harris KM. 1990. Bioecology and Chilo species. Insect Sci. Appl. 11:467-77

72. Harris KM, Nwanze KF. 1992. Busseola fusca (Fuller), the African maize stem borer: a handbook of information. Inf. Bull. 33. ICRISAT. Oxon, UK: CABI. 84 pp.

73. Harris KM, Youm O. 1998. Millet: West Africa. See Ref. 150, pp. 47-48

74. Hawkins BA, Browning HW, Smith JW Jr. 1987. Field evaluation of Allorhogas pyralophagus (Hym.: Braconidae) imported into Texas for biological control of the stalkborer Eoreuma loftini (Lep.: Pyralidae) in sugarcane. Entomophaga 32:483-91

75. Hopper KR, Roush TR. 1993. Mate finding, dispersal, number released, and the success of biological control introductions. Ecol. Entomol. 18:321-31

76. Hutter NJ. 1996. An assessment of the potential value of ten varieties of Napier 
grass (Pennisetum purpureum) with respect to their use as a trap crop for the spotted stemborer (Chilo partellus) attacking maize (Zea mays). MSc thesis. Univ. Newcastle-upon-Tyne, UK. 120 pp.

77. IITA. 1990. Final Tech. Rep. IITA/ USAID/Zaire Appl. Agric. Res. Outreach Proj. IITA, Ibadan, Nigeria

78. Ingram WR. 1958. The lepidopterous stalk-borers associated with Gramineae in Uganda. Bull. Entomol. Res. 49:367-83

79. Ingram WR. 1983. Biological control of graminaceous stem-borers and legume pod borers. Insect Sci. Appl. 4:205-9

80. Ingram WR, Irving NS, Roome RE. 1973. A Handbook on the Control of Agricultural Pests in Botswana. Gaborone: Gov. Printer. 129 pp.

81. Jepson WF. 1954. A Critical Review of the World Literature on the Lepidopterous Stalk Borers of Tropical Graminaceous Crops. London: Commonw. Inst. Entomol. 127 pp.

82. Kaufmann T. 1983. The behavioral biology, feeding habits and ecology of three species of maize stem borers, Eldana saccharina, Sesamia calamistis and Busseola fusca in Ibadan, Nigeria, West Africa. $J$. Ga. Entomol. 18:259-72

83. Kfir R. 1988. Hibernation by the lepidopteran stalk borers, Busseola fusca and Chilo partellus on grain sorghum. Entomol. Exp. Appl. 48:31-36

84. Kfir R. 1990. Prospects for cultural control of the stalk borers, Chilo partellus (Swinhoe) and Busseola fusca (Fuller), in summer grain crops in South Africa. $J$. Entomol. Soc. S. Afr. 53:41-47

85. Kfir R. 1991. Duration of diapause in the stem borers, Busseola fusca and Chilo partellus. Entomol. Exp. Appl. 61:265-70

86. Kfir R. 1991. Effect of diapause on development and reproduction of the stem borers Busseola fusca (Lepidoptera: Noctuidae) and Chilo partellus (Lepidoptera: Pyralidae). J. Econ. Entomol. 84:1677-80

87. Kfir R. 1991. Non-chemical control of grain stalk borers. Plant Prot. News 23:4
88. Kfir R. 1992. Alternative, non-chemical control methods for the stalk borers, Chilo partellus (Swinhoe) and Busseola fusca (Fuller), in summer grain crops in South Africa. Tech. Commun. Dep. Agric. Dev., Rep. S. Afr. 232:99-103

89. Kfir R. 1993. Diapause termination in Busseola fusca (Lepidoptera: Noctuidae) in the laboratory. Ann. Entomol. Soc. Am. 86:273-77

90. Kfir R. 1993. Diapause termination in the spotted stem borer, Chilo partellus (Lepidoptera: Pyralidae) in the laboratory. Ann. Appl. Biol. 123:1-7

91. Kfir R. 1994. Attempts at biological control of the stem borer Chilo partellus (Swinhoe) (Lepidoptera: Pyralidae) in South Africa. Afr. Entomol. 2:67-68

92. Kfir R. 1997. Competitive displacement of Busseola fusca (Lepidoptera: Noctuidae) by Chilo partellus (Lepidoptera: Pyralidae). Ann. Entomol. Soc. Am. 90: 620-24

93. Kfir R. 1997. Natural control of the cereal stemborers Busseola fusca and Chilo partellus in South Africa. Insect Sci. Appl. 17:61-68

94. Kfir R. 1998. Maize and grain sorghum: southern Africa. See Ref. 150, pp. 29-37

95. Kfir R. 2000. Seasonal occurrence, parasitoids and pathogens of the African stem borer, Busseola fusca (Fuller) (Lepidoptera: Noctuidae), on cereal crops in South Africa. Afr. Entomol. :1-14

96. Kfir R, Bell R. 1993. Intraseasonal changes in populations of the African maize stem borer, Busseola fusca (Fuller) (Lepidoptera: Noctuidae), in Natal, South Africa. J. Afr. Zool. 107:543-53

97. Kfir R, Van Hamburg H, Van Vuuren R. 1989. Effect of stubble treatment on the post-diapause emergence of the stalk borer Chilo partellus (Swinhoe) (Lepidoptera: Pyralidae). Crop Prot. 8:289-92

98. Khan ZR, Ampong-Nyarko K, Chiliswa P, Hassanali A, Kimani S, et al. 1997. Intercropping increases parasitism of pests. Nature 388:631-32 
99. Khan ZR, Chiliswa P, Ampong-Nyarko K, Smart LE, Polaszek A, et al. 1997. Utilization of wild gramineous plants for cereal stemborers in Africa. Insect Sci. Appl. 17:143-50

100. Khan ZR, Pickett JP, Van den Berg J, Wadhams LJ, Woodcock CM. 2000. Exploiting chemical ecology and species diversity: stem borer and striga control for maize and sorghum in Africa. Pest Manag. Sci. 56:957-62

101. Kioko EN, Overholt WA, Mueke JM. 1995. Larval development in Chilo orichacociliellus and Chilo partellus: a comparative study in the laboratory. Proc. Meet. Sci. Conf. Afr. Assoc. Insect Sci., 10th, Mombasa, 1993, pp. 191-98. Nairobi: Afr. Assoc. Insect Sci.

102. Lawani SM. 1982. A review of the effects of various agronomic practices on cereal stem borer populations. Trop. Pest Manag. 28:266-76

103. Leslie GW. 1988. The identification and importance of predators of Eldana saccharina (Lepidoptera: Pyralidae). Proc. S. Afr. Sugar Tech. Assoc. 67:122-26

104. MacArthur RH, Wilson EO. 1967. The Theory of Island Biogeography. Princeton, NJ: Princeton Univ. Press. 208 pp.

105. Maes K. 1998. Pyraloidea: Crambidae, Pyralidae. See Ref. 150, pp. 87-98

106. Mally CW. 1920. The maize stalk borer Busseola fusca (Fuller). Bull. Dep. Agric. S. Afr., 3. $111 \mathrm{pp}$.

107. Matama-Kauma T. 2000. Yield losses caused by stem borers on maize and establishment of Cotesia flavipes Cameron (Hymenoptera: Braconidae) in Eastern Uganda. MSc thesis. Makerere Univ., Kampala. 98 pp.

108. Mathez FC. 1972. Chilo partellus Swinh., C. orichalcociliellus Strand (Lep., Crambidae) and Sesamia calamistis Hmps. (Lep., Noctuidae) on maize in the Coast Province, Kenya. Mitt. Schweiz. Entomol. Ges. 45:267-89

109. Matthee JJ. 1974. Pests of graminaceous crops in South Africa. Entomol. Mem. 40,
Dep. Agric. Tech. Serv., Rep. S. Afr., 24 pp.

110. McFarlane J. 1990. Damage assessment and yield losses in sorghum due to the stem borer Busseola fusca (Fuller) (Lepidoptera: Noctuidae) in northern Nigeria. Trop. Pest Manag. 36:131-37

111. Mchowa JW. 1990. The effect of planting date on the incidence of the stalk borers, Busseola fusca (Fuller) (Lepidoptera: Noctuidae) and Chilo partellus (Swinhoe) (Lepidoptera: Pyralidae) in two varieties of sorghum. Proc. Reg. Workshop Sorghum Millets South. Afr., SADCC Conf., 6th, Bulawayo, 1989, pp. 154-59. Bulawayo, Zimbabwe: ICRISAT

112. Megenasa T. 1982. Insect pests of sorghum in Ethiopia. Proc. Reg. Workshop Sorghum Improvement East. Afr., 1982, pp. 54-64. Nazareth/Debre Zeit, Ethiopia: Sorghum Improv. Proj.

113. Minja EM. 1990. Management of Chilo spp. infesting cereals in eastern Africa. Insect Sci. Appl. 11:489-99

114. Mohyuddin AI. 1971. Comparative biology and ecology of Apanteles flavipes (Cam.) and A. sesamiae (Cam.) as parasites of graminaceous borers. Bull. Entomol. Res. 61:33-39

115. Mohyuddin AI, Greathead DJ. 1970. An annotated list of the parasites of graminaceous stem borers in East Africa, with a discussion of their potential in biological control. Entomophaga 15:241-74

116. Mohyuddin AI, Inayatullah C, King EG. 1981. Host selection and strain occurrence in Apanteles flavipes (Cameron) (Hymenoptera: Braconidae) and its bearing on biological control of graminaceous stemborers (Lepidoptera: Pyralidae). Bull. Entomol. Res. 71:575-81

117. Moutia LA, Courtois CM. 1952. Parasites of the moth-borers of sugar-cane in Mauritius. Bull. Entomol. Res. 43:325-59

118. Moyal P. 1995. Borer infestation and damage in relation to maize stand density and water stress in the Ivory Coast. Int. J. Pest Manag. 41:114-21 
119. Moyal P. 1998. Infestation patterns and parasitism of the maize stalk borer, Busseola fusca (Fuller) (Lepidoptera: Noctuidae), in the Ivory Coast. Afr. Entomol. 6:289-96

120. Moyal P, Tran M. 1992. Chilo aleniellus (Lepidoptera: Pyralidae), a stem borer of maize in Côte d'Ivoire. Bull. Entomol. Res. 82:67-72

121. Muyango S. 1987. Les chenilles foreuses des tiges du maïs et du sorgho: écologie et lutte. In Séminaire sur les maladies et les ravageurs des principles cultures vivrières d'Afrique Centrale, pp. 11726. Ede/Wageningen: Centre Tech. Coop. Agric. Rurale (CTA)

122. Nagarkatti S, Nair KR. 1973. The influence of wild and cultivated Gramineae and Cyperaceae on populations of sugarcane borers and their parasites in North India. Entomophaga 18:419-30

123. Ngi-Song AJ, Overholt WA, Ayertey JN. 1995. Suitability of African gramineous stemborers for the development of Cotesia flavipes and Cotesia sesamiae (Hymenoptera: Braconidae). Environ. Entomol. 24:978-84

124. Ngi-Song AJ, Overholt WA, Njagi PGN, Dicke M, Ayertey JN, Lwande W. 1996. Volatile infochemicals used in host and host habitat location by Cotesia flavipes Cameron and Cotesia sesamiae (Cameron) (Hymenoptera: Braconidae), larval parasitoids of stemborers on Graminae. J. Chem. Ecol. 22:307-22

125. Nunes E, Sousa D, Sataric I. 1985. Research on the constraints to maize production in Mozambique. To feed ourselves. Proc. First East., Cent. South. Afr. Reg. Maize Workshop, Lusaka, Zambia

126. Nwanze KF, Mueller RAE. 1989. Management options for sorghum stem borers for farmers in the semi-arid tropics. Int. Workshop Sorghum Stem Borers, Patancheru, 1987, ed. KF Nwanze. pp. 105-14. Patancheru, India: ICRISAT

127. Nye IWR. 1960. The insect pests of graminaceous crops in East Africa. Colonial
Res. Stud. 31. London: Her Majesty's Stationary Off. $48 \mathrm{pp}$.

128. Odindo MO. 1990. Potential of Nosema spp. (Microspora, Nosematidae) and viruses in the management of Chilo spp. (Lepidoptera, Pyralidae). Insect Sci. Appl. 12:645-51

129. Ofomata VC. 1997. Ecological interactions between Chilo orichalcociliellus Strand and Chilo partellus (Swinhoe) (Lepidoptera: Pyralidae) on the Kenya coast. PhD thesis. Nnamdi Azikiwe Univ., Anambra State, Nigeria. 206 pp.

130. Ofomata VC, Overholt WA, Egwuatu RI. 1999. Diapause termination of Chilo partellus (Swinhoe) and Chilo orichalcociliellus Strand (Lepidoptera: Pyralidae). Insect Sci. Appl. 19:187-91

131. Ofomata VC, Overholt WA, Lux SA, Van Huis A, Egwuatu RI. 2000. Comparative studies on the fecundity, egg survival, larval feeding and development of Chilo partellus (Swinhoe) and Chilo orichalcociliellus Strand (Lepidoptera: Crambidae) on five grasses. Ann. Entomol. Soc. Am. 93:492-99

132. Ofomata VC, Overholt WA Van Huis A, Egwuatu RI, Ngi-Song AJ. 1999. Niche overlap and interspecific association between Chilo partellus and Chilo orichalcociliellus on the Kenya coast. Entomol. Exp. Appl. 93:141-48

133. Ogedah KO. 1999. Evaluation of the impact of Cotesia flavipes Cameron (Hymenoptera: Braconidae) and indigenous parasitoids on stemborer populations in southwestern Kenya. MSc thesis. Kenyatta Univ., Nairobi. 71 pp.

134. Ogunwolu EO, Nwosu K, Ogunyebi SO. 1981. Stem borer damage in maize as affected by host plant density. J. Agric. Sci. 96:695-97

135. Okuda T. 1988. Effect of artificial wetting and rainfall on the larval diapause of a stem borer, Busseola fusca in western Kenya. Entomol. Exp. Appl. 48:263-67

136. Okuda T. 1990. Significance of water contact as a factor terminating larval diapause 
in a stem borer, Busseola fusca. Entomol. Exp. Appl. 57:151-55

137. Okuda T. 1991. Factors inducing and terminating larval diapause in a stem borer, Busseola fusca in western Kenya. Jpn. Agric. Res. Q. 25:47-54

138. Oloo GW, Ogeda K. 1990. The incidence of Chilo partellus (Swinh.) (Pyralidae) and the contribution of natural enemies to its mortality under intercropping systems in Kenya. Insect Sci. Appl. 10:243-51

139. Omwega CO, Kimani SW, Overholt WA, Ogol CKPO. 1995. Evidence of the establishment of Cotesia flavipes Cameron (Hymenoptera: Braconidae) in continental Africa. Bull. Entomol. Res. 85:525-30

140. Omwega CO, Overholt WA, Mbapila JC, Kimani-Njogu SW. 1997. Establishment and dispersal of Cotesia flavipes Cameron (Hymenoptera: Braconidae), an exotic endoparasitoid of Chilo partellus Swinhoe (Lepidoptera: Pyralidae) in northern Tanzania. Afr. Entomol. 5:71-75

141. Overholt WA. 1998. Biological control. See Ref. 150, pp. 349-62

142. Overholt WA, Ngi-Song AJ, Kimani SK, Mbapila J, Lammers P, Kioko E. 1994. Ecological considerations of the introductions of Cotesia flavipes Cameron (Hymenoptera: Braconidae) for biological control of Chilo partellus (Swinhoe) (Lepidoptera: Pyralidae), in Africa. Biocontrol News Inf. 15:19-24

143. Overholt WA, Ngi-Song AJ, Omwega CO, Kimani-Njogu SW, Mbapila J, et al. 1997. A review of the introduction and establishment of Cotesia flavipes Cameron (Hymenoptera: Braconidae) in East Africa for biological control of cereal stemborers. Insect Sci. Appl. 17:19-35

144. Overholt WA, Ochieng JO, Lammers P, Ogedah K. 1994. Rearing and field release methods for Cotesia flavipes Cameron (Hymenoptera: Braconidae), a parasitoid of tropical gramineous stemborers. Insect Sci. Appl. 15:253-59

145. Overholt WA, Songa JM, Ofomata V, Jeske J. 2000. The spread and ecologi- cal consequences of the invasion of Chilo partellus (Swinhoe) (Lepidoptera: Crambidae) in Africa. In Invasive Species in Eastern Africa: Proc. Workshop ICIPE, 2000, ed. EE Lyons, SE Miller, pp. 5258. Nairobi: ICIPE Sci. Press. 108 pp.

146. Päts P. 1992. Reproductive biology of the cereal stemborers Chilo partellus. $\mathrm{PhD}$ thesis. Swed. Univ. Agric. Sci., Uppsala, Swed. 97 pp.

147. Päts P. 1996. Management of crop residues to reduce the aestivating population of stemborers in maize. Int. J. Pest Manag. 42:151-56

148. Päts P, Ekbom B, Scovgård H. 1997. Influence of intercropping on the abundance, distribution and parasitism of Chilo spp. (Lepidoptera: Pyralidae) eggs. Bull. Entomol. Res. 87:507-13

149. Poinar GO, Polaszek A. 1998. Nematoda, fungi, protozoa, bacteria and viruses. See Ref. 150, pp. 283-93

150. Polaszek A. 1998. African Cereal Stem Borers: Economic Importance, Taxonomy, Natural Enemies and Control. Wallingford, UK: CABI. 530 pp.

151. Polaszek A, Walker AK. 1991. The Cotesia flavipes species complex: parasitoids of cereal stemborers in the tropics. Redia 74:335-41

152. Rajabalee MA, Govendasamy M. 1988. Host specificity and efficacy of Apanteles flavipes (Cam.) and A. sesamiae (Cam.) (Hymenoptera: Braconidae) parasites of sugar cane moth borers in Mauritius. Rev. Agric. Sucr. Ile Maurice 67:78-80

153. Revington J. 1986. This borer spreads rapidly through crops of maize and sorghum on the Highveld, but it can be controlled. Farmer's Weekly, Oct. 24. South Africa

154. Revington J. 1987. Use of a synthetic sex pheromone in forecasting attacks on maize by maize stalkborer Busseola fusca (Fuller) (Lepidoptera: Noctuidae). MSc thesis. Univ. Witwatersrand, Johannesburg. 204 pp.

155. Risch SJ, Andow D, Altieri MA. 1983. 
Agrosystems diversity and pest control: data, tentative conclusions and new research directions. Environ. Entomol. 12:625-29

156. Sagnia SB. 1983. Possible integrated pest management tools for the effective control of cereal stem borers in the Gambia. Insect Sci. Appl. 4:217-19

157. Sallam MN, Overholt WA, Kairu E. 2001. Dispersal of the exotic parasitoid Cotesia flavipes in a new ecosystem. Entomol. Exp. Appl. 98:211-17

158. SASA. 1994. Eldana borer-control measures. Experiment Station Information Sheet: SASA. Mount Edgecombe, Natal: S. Afr. Sugar Assoc.

159. Scheibelreiter GK. 1980. Sugar-cane stem borers (Lepidoptera: Pyralidae and Noctuidae) in Ghana. Z. Angew. Entomol. 89:87-99

160. Scheltes P. 1978. Ecological and physiological aspect of aestivation-diapause in the larvae of two Pyralid stalk borers of maize in Kenya. $\mathrm{PhD}$ thesis. Landbouwhogeschool, Wageningen. $110 \mathrm{pp}$.

161. Scheltes P. 1978. The condition of the host plant during aestivation-diapause of the stalk borers Chilo partellus and Chilo orichalcociliella (Lepidoptera: Pyralidae) in Kenya. Entomol. Exp. Appl. 24:679-88

162. Scovgård H, Päts P. 1996. Effects of intercropping on maize stemborers and their natural enemies. Bull. Entomol. Res. 86:599-607

163. Seshu Reddy KV. 1983. Sorghum stem borers in eastern Africa. Insect Sci. Appl. 4:3-10

164. Seshu Reddy KV. 1985. Integrated approach to the control of sorghum stemborers. Proc. Int. Sorghum Entomol. Workshop, Tex., 1984, pp. 205-15. Patancheru, India: ICRISAT

165. Seshu Reddy KV. 1988. Assessment of on-farm yield losses in sorghum due to insect pests. Insect Sci. Appl. 9:679-85

166. Seshu Reddy KV. 1990. Cultural control of Chilo spp. in graminaceous crops. Insect Sci. Appl. 11:703-12
167. Seshu Reddy KV. 1998. Integrated pest management. See Ref. 150, pp. 39-45

168. Seshu Reddy KV. 1998. Maize and sorghum: East Africa. See Ref. 150, pp. 25-27

169. Seshu Reddy KV, Sum KOS. 1991. Determination of economic injury level of the stem borer, Chilo partellus (Swinhoe) in maize, Zea mays L. Insect Sci. Appl. 12:269-74

170. Seshu Reddy KV, Sum KOS, Lubega MC. 1989. Empirical models for predicting yield loss in sorghum caused by Chilo partellus (Swinhoe). Discov. Innov. 1:9094

171. Sétamou M, Schulthess F, Bosque-Pérez NA, Thomas-Odjo A. 1993. Effect of plant nitrogen and silica on the bionomics of Sesamia calamistis Hampson (Lepidoptera: Noctuidae). Bull. Entomol. Res. 83:405-11

172. Sétamou M, Schulthess F, Bosque-Pérez NA, Thomas-Odjo A. 1995. The effect of stem and cob borers on maize subjected to different nitrogen and silica treatments, with special reference to Sesamia calamistis Hampson (Lepidoptera: Noctuidae). Entomol. Exp. Appl. 77:205-10

173. Shami S, Mohyuddin AI. 1987. Host selection by Indonesian strain of Apanteles flavipes (Cam.) and its suitability for various graminaceous borers in Pakistan. Proc. Annu. Conv. Pak. Soc. Sugar Technol., 23rd, Rawalpindi, pp. 286-91. Rawalpindi: Pak. Soc. Sugar Technol.

174. Shanower TG, Schulthess F, BosquePérez NA. 1994. The effect of larval diet on the growth and development of Sesamia calamistis Hampson (Lepidoptera: Noctuidae) and Eldana saccharina Walker (Lepidoptera: Pyralidae). Insect Sci. Appl. 14:681-85

175. Shanower TG, Schulthess F, Gounou S. 1991. Distribution and abundance of some stem and cob borers in Benin. Plant Health Manag. Div., Res. Monogr. 1. IITA, Cotonou, Benin

176. Sibanda S. 1985. The use of sorghum and 
millets for feeding livestock. Proc. Reg. Workshop Sorghum Millets for S. Afr., 2nd, Gaborone, pp. 228-47. Gaborone, Botswana

177. Sithole SZ. 1987. Maize insect pests in Zimbabwe. Toward Insect Resistant Maize for the Third World. Proc. Int. Symp. Methodol. Developing Host Plant Resistance Maize Insects, Mexico, pp. 286-88. Mexico City: Centro Int. Majoramiento Maiz y Trigo

178. Sithole SZ. 1989. Sorghum stem borers in southern Africa. Int. Workshop Sorghum Stem Borers, Patancheru, 1987, ed. KF Nwanze, pp. 41-47. Patancheru, India: ICRISAT

179. Sithole SZ. 1989. The effect of date of planting on shootfly and stem borer infestations on sorghum. Proc. Reg. Workshop Sorghum Millets S. Afr., 3rd, Lusaka, 1986, pp. 174-83. Patancheru: ICRISAT

180. Sithole SZ. 1990. Status and control of the stem borer, Chilo partellus (Swinhoe) (Lepidoptera: Pyralidae) in southern Africa. Insect Sci. Appl. 11:481-88

181. Skoroszewski RW, Van Hamburg H. 1987. The release of Apanteles flavipes (Cameron) (Hymenoptera: Braconidae) against stalk-borers of maize and grainsorghum in South Africa. J. Entomol. Soc. S. Afr. 50:249-55

182. Smith JW Jr, Wiedenmann RN, Overholt WA. 1993. Parasites of Lepidopteran Stemborers of Tropical Gramineous Plants. Nairobi: ICIPE Sci. Press. 89 pp.

183. Songa JM. 1999. Distribution, importance and management of stemborers (Lepidoptera) in maize production systems of semi-arid eastern Kenya with emphasis on biological control. $\mathrm{PhD}$ thesis. Kenyatta Univ., Nairobi. 251 pp.

184. Starks KJ. 1969. Some cereal crop insects in east Africa. East Afr. Agric. For. Res. Organ., Serere Res. Stn., Uganda

185. Swaine G. 1957. The maize and sorghum stalkborer, Busseola fusca (Fuller), in peasant agriculture in Tanganyika territory. Bull. Entomol. Res. 48:711-22
186. Tams WHT. 1932. New species of African Heterocera. Entomologist 65:1241-49

187. Tams WHT, Bowden J. 1953. A revision of the African species of Sesamia Guenee and related genera (AgrotidaeLepidoptera). Bull. Entomol. Res. 43: 645-78

188. Taneja SL, Nwanze KF. 1989. Assessment of yield loss of sorghum and pearl millet due to stem borer damage. Int. Workshop Sorghum Stem Borers, Patancheru, 1987, ed. KF Nwanze, pp. 95-104. Patancheru, India: ICRISAT

189. Tavakilian G. 1977. Le genre Chilo en Côte d'Ivoire. Cah. ORSTOM Sér. Biol. 12:47-54

190. Tran M. 1977. Morphologie des pièces génitales et nervation alaire des principales pyrales foreurs du riz en Côte d'Ivoire. Description de quelques Hyménoptères parasites. Cah. ORSTOM Sér. Biol. 12:29-45

191. Ukwungwu MN. 1985. Effect of nitrogen and carbofuran on gall midge (GM) and white stem borer (SB) infestation in Nigeria. Int. Rice Res. Newsl. 10:19-20

192. Unnithan GC, Seshu Reddy KV. 1989. Incidence, diapause and carryover of the cereal stem borers in Rusinga Island, Kenya. Trop. Pest Manag. 35:414-19

193. Usua EJ. 1973. Induction of diapause in the maize stemborer, Busseola fusca. Entomol. Exp. Appl. 16:322-28

194. Usua EJ. 1974. Observations on the physiology of diapause and non-diapause larvae of Busseola fusca (Fuller) (Lep., Noctuidae). Bull. Entomol. Res. 63:513-18

195. Van den Berg J, Nur AF. 1998. Chemical control. See Ref. 150, pp. 319-32

196. Van den Berg J, Nur AF, Polaszek A. 1998. Cultural control. See Ref. 150, pp. 333-47

197. Van den Berg J, Van Rensburg JBJ. 1991. Infestation and injury levels of stem borers in relation to yield potential of grain sorghum. S. Afr. J. Plant Soil 8:12731

198. Van den Berg J, Van Rensburg JBJ. 1991. 
The effect of plant density on the injuriousness of Busseola fusca (Fuller) (Lepidoptera: Noctuidae) in grain sorghum. $S$. Afr. J. Plant Soil 8:85-87

199. Van den Berg J, Van Rensburg JBJ, Pringle KL. 1990. Damage caused by Chilo partellus (Swinhoe) (Lepidoptera: Pyralidae) to various cultivars of grain sorghum, Sorghum bicolor (L.) Moench. S. Afr. J. Plant Soil 7:192-96

200. Van den Berg J, Van Rensburg JBJ, Pringle KL. 1991. Comparative injuriousness of Busseola fusca (Lepidoptera: Noctuidae) and Chilo partellus (Lepidoptera: Pyralidae) on grain sorghum. Bull. Entomol. Res. 81:137-42

201. Van den Berg J, Van Rensburg JBJ, Van der Westhuizen MC. 1991. The effect of single and mixed populations of Busseola fusca (Lepidoptera: Noctuidae) and Chilo partellus (Lepidoptera: Pyralidae) on damage to grain sorghum. J. Entomol. Soc. S. Afr. 54:231-42

202. Van den Berg J, Van Rensburg JBJ, Van der Westhuizen MC. 1993. Status of resistance to Chilo partellus (Lepidoptera: Pyralidae) in South African grain sorghum hybrids. S. Afr. J. Plant Soil 10: 174-77

203. Van Hamburg H. 1976. Die bionomie en ekonomiese belangrikheid van die graansorghum-stamruspe, Chilo partellus (Swinhoe) (Lepidoptera: Pyralidae). DSc thesis. Univ. Pretoria, Pretoria. 299 pp.

204. Van Hamburg H. 1979. The grainsorghum stalk-borer, Chilo partellus (Swinhoe) (Lepidoptera: Pyralidae): seasonal changes in adult populations in grain sorghum in the Transvaal. J. Entomol. Soc. S. Afr. 42:1-9

205. Van Hamburg H. 1987. A biological control approach to pest management on grain crops with special reference to the control of stalkborers. Tech. Commun., Dep. Agric. Water Supply, Rep. S. Afr. 212:5255

206. Van Rensburg GDJ, Bate R. 1987. Pre- liminary studies on the relative abundance and distribution of the stalk borers Busseola fusca and Chilo partellus Tech. Commun., Dep. Agric. Water Supply, Rep. S. Afr. 212:49-52

207. Van Rensburg JBJ. 1992. Evaluation of pheromone trapping systems in relation to light trap captures of the maize stalk borer Busseola fusca (Fuller) (Lepidoptera: Noctuidae). S. Afr. J. Plant Soil 9:144-49

208. Van Rensburg JBJ. 1997. Seasonal moth flight activity of the maize stem borer, Busseola fusca (Fuller) (Lepidoptera: Noctuidae) in small farming areas of South Africa. Appl. Plant Sci. 11:20-23

209. Van Rensburg JBJ, Drinkwater TW, Carnegie AJM, Eulitz EG, Rust D. 1989. Stemborers. In Crop Pests in Southern Africa, ed. AC Myburgh, 4:64-73, Bull. 416. Pretoria: Plant Prot. Res. Inst., Dep. Agric. Water Supply. 156 pp.

210. Van Rensburg JBJ, Walters MC, Giliomee JH. 1985. Geographical variation in the seasonal moth flight activity of the maize stalk borer, Busseola fusca (Fuller), in South Africa. S. Afr. J. Plant Soil 2:12426

211. Van Rensburg JBJ, Walters MC, Giliomee JH. 1988. Plant population and cultivar effects on yield losses caused by the maize stalk borer, Busseola fusca (Lepidoptera: Noctuidae). S. Afr. J. Plant Soil 5:215-18

212. Van Rensburg JBJ, Walters MC, Giliomee JH. 1989. Selective oviposition by the maize stalk borer, Busseola fusca (Fuller). J. Entomol. Soc. S. Afr. 52:105-8

213. Van Rensburg NJ, Van Hamburg H. 1975. Grain sorghum pests: an integrated control approach. Proc. Congr. Entomol. Soc. S. Afr., 1st, Pretoria, pp. 151-62. Pretoria: Entomol. Soc. S. Afr.

214. Waage JK. 1990. Ecological theory and the selection of biological control agents. In Critical Issues in Biological Control, ed. M Mackauer, LE Ehler, J Roland, pp. 135-58. Andover, UK: Intercept. 330 pp. 
215. Walker PT. 1960. The relation between infestation by the stalk borer Busseola fusca, and yield of maize in East Africa. Ann. Appl. Biol. 48:780-86

216. Walker PT, Hodson MJ. 1976. Developments in maize stem-borer control in East Africa, including the use of insecticide granules. Ann. Appl. Biol. 84:11114

217. Warui CM, Kuria JN. 1983. Population incidence and the control of maize stalkborers Chilo partellus (Swinh.) and Chilo orichalcociliellus Strand and Sesamia calamistis Hmps. in Coast Province, Kenya. Insect Sci. Appl. 4:11-18

218. Way MJ, Kfir R. 1997. The stem borer Chilo partellus (Swinhoe) in sugarcane in southern Africa. Afr. Entomol. 5:17072

219. Wiedenmann RN, Smith JW Jr. 1993. Functional response of the parasite Cotesia flavipes (Hymenoptera: Braconidae) at low densities of the host Diatraea saccharalis (Lepidoptera: Pyralidae). Environ. Entomol. 22:848-58

220. Wiedenmann RN, Smith JW Jr. 1997. Novel associations and importation biological control: the need for ecological and physiological equivalencies. Insect Sci. Appl. 17:51-60

221. Wilkinson H. 1939. Entomol. Sect. Annu. Rep. 2. Dep. Agric., Kenya

222. Williams JR. 1983. The sugar cane stem borer (Chilo sacchariphagus) in Mauri- tius. Rev. Agric. Sucr. Ile Maurice 62:523

223. Yitaferu K, Gebre-Amlak A. 1994. Phenology and survival of the maize stalk borer, Busseola fusca in eastern Ethiopia. Insect Sci. Appl. 15:177-84

224. Youdeowi A. 1989. Major arthropod pests of food and industrial crops of Africa and their economic importance. In Biological Control: A Sustainable Solution to Crop Pest Problems in Africa, ed. JS Yanninek, HR Herren, pp. 51-60. Ibadan, Nigeria: Int. Inst. Trop. Agric. 210 pp.

225. Youm O, Beevor PS. 1995. Field evaluation of pheromone-baited traps for Coniesta ignefusalis (Lepidoptera: Pyralidae) in Niger. J. Econ. Entomol. 88:65-69

226. Youm O, Gilstrap FE. 1994. Habitat site selection, crop damage and oviposition preference by Coniesta (=Haimbachia) ignefusalis (Lepidoptera: Pyralidae). Int. J. Pest Manag. 40:231-36

227. Youm O, Mamalo AK, Nwanze KF. 1993. Bio-ecology and integrated management of the millet stem borer (Lepidoptera: Pyralidae): a review and highlights of current research at the ICRISAT Sahelian Center. Proc. Reg. Pearl Millet Workshop, Niamey, 1990, pp. 55-63. Niamey, Niger: ICRISAT Sahelian Cent.

228. Zhou G, Baumgartner J, Overholt WA. 2001. Impact of an exotic parasitoid on stemborer (Lepidoptera) populations dynamics in Kenya. Ecol. Appl. 11:1554-62 